\title{
Microcos antidesmifolia (Malvaceae-Grewioideae), a poorly known species in Singapore
}

\author{
S.K. Ganesan ${ }^{1}$, R.C.J. Lim², P.K.F. Leong ${ }^{1} \&$ X.Y. $\mathrm{Ng}^{2}$ \\ ${ }^{1}$ Singapore Botanic Gardens, National Parks Board, \\ 1 Cluny Road, 259569 Singapore \\ s_k_ganesan@nparks.gov.sg \\ ${ }^{2}$ Native Plant Centre, Horticulture and Community Gardening Division, \\ National Parks Board, 100K Pasir Panjang Road, \\ 118526 Singapore
}

\begin{abstract}
A poorly known species in Singapore, Microcos antidesmifolia (King) Burret, is described and illustrated for the first time. In Singapore, it is known from the type variety, Microcos antidesmifolia (King) Burret var. antidesmifolia. Notes on distribution, ecology and conservation status are given. This species is assessed as Critically Endangered for Singapore. A key is given for the five Microcos L. species in Singapore.
\end{abstract}

Keywords. Conservation assessment, distribution, ecology, flora

\section{Introduction}

The genus Microcos L. comprises about 80 species that are distributed in tropical Africa (not in Madagascar), India, Sri Lanka, Myanmar, Indochina, south China and throughout Malesia (except the Lesser Sunda Islands) (Chung \& Soepadmo, 2011). Until about 2007, Microcos was placed in the family Tiliaceae. However, phylogenetic analysis using both molecular and morphological data has led to the recognition of an expanded Malvaceae, composed of the formerly recognised families Malvaceae s.s., Tiliaceae, Bombacaceae and Sterculiaceae, and for the Malvaceae s.l. to be divided into nine sub-families (Alverson et al., 1999; Bayer et al., 1999; Bayer \& Kubitzki, 2003). This classification was adopted by the Angiosperm Phylogeny Group (APG, 2009, 2016). Here we follow APG and consider Microcos in Malvaceae, subfamily Grewioideae Dippel. Chung \& Soepadmo (2011) recorded four species of Microcos in Singapore (M. globulifera (Mast.) Burret, M. hirsuta (Korth.) Burret, M. latifolia Burret, and M. tomentosa Sm.). An additional species, Microcos antidesmifolia (King) Burret, represented in Singapore by $M$. antidesmifolia var. antidesmifolia, was published in a checklist of the Nee Soon swamp forest in Singapore by Wong et al. (2013), bringing the total number of Microcos species in Singapore to five. However, apart from stating a conservation assessment of "presumed nationally extinct" in Wong et al (2013), no specimen data were provided, there is no description of this species in Singapore, and there is scant information on its overall distribution and ecology nationally. 
In January 2020, fertile specimens of Microcos were collected from remnant mixed dipterocarp forest in the Central Catchment Nature Reserve in Singapore. These specimens have a combination of the following characters that identify them as Microcos antidesmifolia (King) Burret var. antidesmifolia, and that are unlike those of any other Microcos species in Singapore: stipules caducous and lanceolate, leaf margin entire, leaf blade chartaceous, leaf midrib flat above, petiole apically not swollen, fruits pyriform in shape with a pseudostalk.

Based on these new collections, the conservation status for Microcos antidesmifolia (King) Burret var. antidesmifolia stated as 'presumed nationally extinct' in Wong et al. (2013) no longer applies. Here the species is described and illustrated from Singapore for the first time, along with notes on its distribution, ecology and an updated conservation assessment. Also, a key to all species of Microcos in Singapore is provided.

\section{Taxonomy}

Microcos antidesmifolia (King) Burret, Notizbl. Bot. Gart. Berlin-Dahlem 9: 780 (1926); Chung \& Soepadmo, Blumea 56: 275 (2011). - Grewia antidesmifolia King, J. Asiat. Soc. Bengal, Pt. 2, Nat. Hist. 60, 1: 113 (1891); Ridley, Fl. Malay Penins. 1: 302 (1922). - TYPE: [Peninsular Malaysia], Perak, Larut, March 1883, King's Collector 4029 (lectotype K [K000686832], designated by Chung et al. (2005)). (Fig. 1).

\section{var. antidesmifolia}

Tree about $8 \mathrm{~m}$ tall (in Peninsular Malaysia, up to $24 \mathrm{~m}$ tall). Twigs terete, grey, glabrescent, hairs stellate brown. Stipules caducous, lanceolate, densely stellate hairy on both sides. Leaves distichous; petiole densely stellate hairy, $6.0-8.5 \mathrm{~cm}$ long, apically not swollen; blade narrowly-elliptic, 5-11 × 2-3.5 cm, slightly lustrous when young, maturing mid to dark green, drying greenish-brown, chartaceous, glabrous above except for midrib and basal and secondary veins that are densely stellate hairy, yellowish-green below with indumentum similar to above except domatia sometimes present, base cuneate, symmetrical, apex blunt acuminate, margin entire, slightly revolute, midrib visible and flat above, prominent below, secondary veins 6-7 pairs (including 1 pair of basal veins), visible and flat above, prominent below, tertiary veins more or less scalariform, visible and flat above, prominent below, quaternary veins obscure and flat above, conspicuous and prominent below. Inflorescences terminal and axillary, Type B panicles (sensu Chung \& Soepadmo, 2011), densely stellate hairy; inflorescence bracts caducous, narrowly oblong, densely stellate hairy on both sides, 3.0-3.5 mm long. Flowers greenish-yellow; outer involucral bracts 2-3 cleft, densely hairy on both sides, 4.0-4.5 mm long, lobes triangular, c. $1 \mathrm{~mm}$ long, smooth on outer surface; inner involucral bracts entire, oblanceolate, c. $3 \mathrm{~mm}$ long, densely stellate hairy on both sides; buds oblanceolate, densely stellate hairy, fully open flowers not yet known from Singaporean material. Fruits pyriform, ripening orange, 

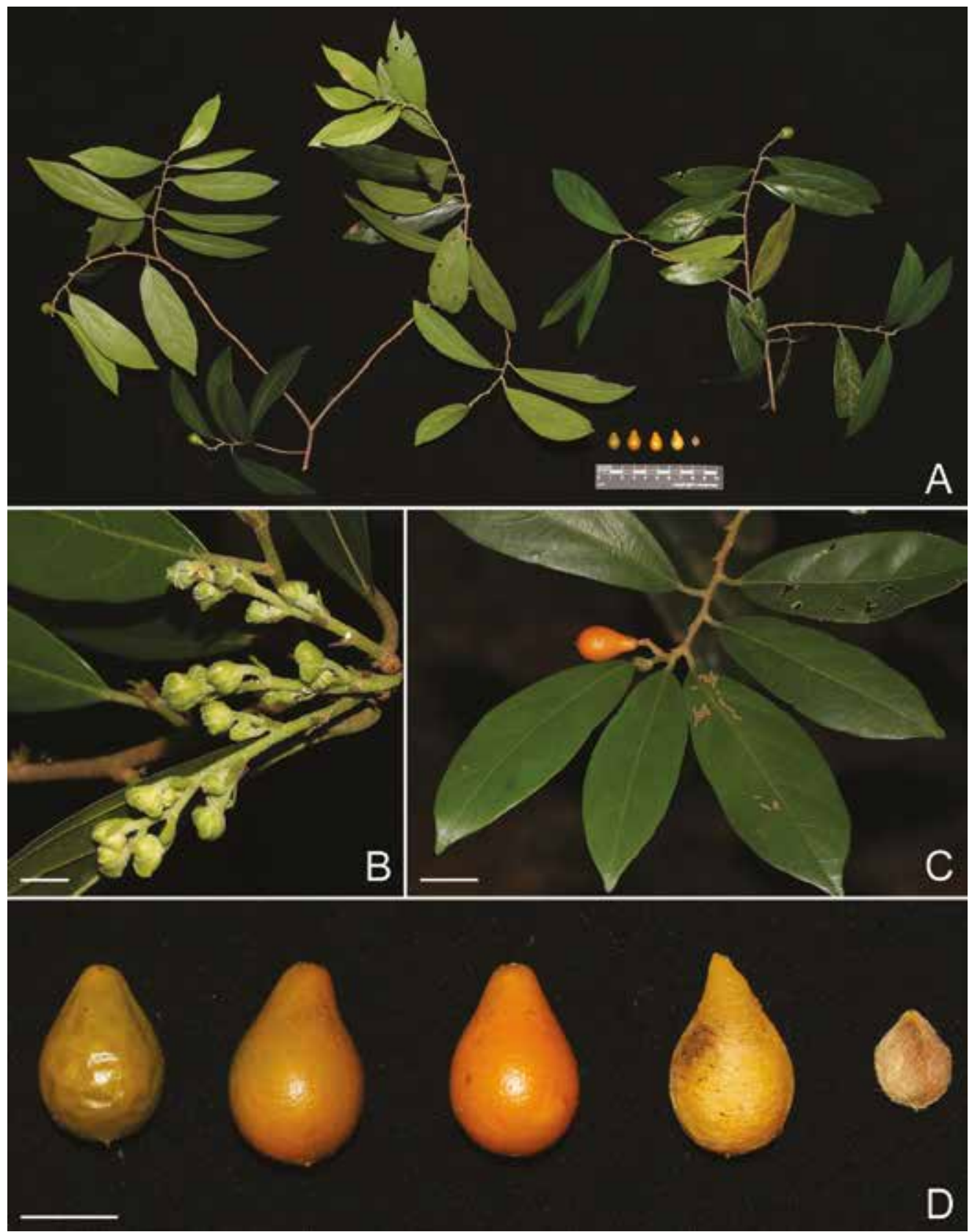

Fig. 1. Microcos antidesmifolia (King) Burret var. antidesmifolia. A. Fruiting branch. B. Inflorescences. C. Close up of fruiting branch. D. Fruits at different stages of maturity (from left to right) and its endocarp (far right-hand side). Scale bars: B-D = $1 \mathrm{~cm}$. A, C \& D from Lim SING2020-67; B from Lim SING2020-199. (Photos: X.Y. Ng). 
glabrous, $15-16 \times 8.5-9.0 \mathrm{~mm}$; pseudostalk 3.0-10 mm long, exocarp membranous; mesocarp fibrous; endocarp woody; pyrenes $3-4$, fertile pyrenes $1-2$, sterile pyrene 1 , conspicuous. Seed one.

Distribution. Formerly considered endemic to Peninsular Malaysia, now found extending southwards to Singapore.

Ecology. In Peninsular Malaysia, it is found in freshwater swamp forest, lowland to hill dipterocarp and secondary forests. In Singapore it is found in a patch of mixed dipterocarp forest within Nee Soon swamp forest.

Provisional IUCN conservation assessment. Only one mature tree has been seen in Singapore (the specimens collected are from this tree), with other smaller saplings less than $1 \mathrm{~m}$ tall and seedlings in the immediately vicinity. As there are fewer than 50 mature individuals, the national conservation status of Microcos antidesmifolia var. antidesmifolia in Singapore is assessed here as Critically Endangered (CR/D), following the criteria adapted by Davison (2008) from earlier IUCN guidelines. There is no global conservation assessment of this species, but its presence in secondary forests elsewhere suggests tolerance of disturbed sites and therefore it is not likely to be globally endangered. However, it is not known whether the distribution of this species is beyond the threshold for $\mathrm{VU}$ or that it is known from $>10$ populations if within the threshold. This information will be available when the treatment for this species is completed for the Flora of Peninsular Malaysia.

Specimens examined. SINGAPORE: Nee Soon Swamp: Seletar, 23 Jan 2020, Lim SING2020067 (SING) (fl. bud); ibidem, 19 Feb 2020, Lim SING 2020-199 (SING) (fr.).

Notes. Peninsular Malaysian material will be used to augment the description for the forthcoming Flora of Singapore account, along with material from the Singaporean tree if it flowers before publication.

Microcos antidesmifolia has two varieties, the one described above and $M$. antidesmifolia var. hirsuta (King) Burret. Microcos antidesmifolia var. antidesmifolia differs from M. antidesmifolia var. hirsuta in the following: leaf blade more or less glabrous below (versus sparsely hairy in M. antidesmifolia var. hirsuta), leaf base symmetrical (versus asymmetrical in M. antidesmifolia var. hirsuta), and inflorescences only Type B (versus both Types A and B in M. antidesmifolia var. hirsuta). Microcos antidesmifolia var. antidesmifolia is distributed in Peninsular Malaysia and Singapore (versus Peninsular Malaysia and Borneo for M. antidesmifolia var. hirsuta).

The National University of Singapore team involved in the Nee Soon Swamp Forest floristic survey has also found a separate individual in the same area, about 0.5 $\mathrm{m}$ tall. More populations or individuals may be found if an extensive survey is to be done of the area. However, the number of mature individuals is not expected to exceed 50 . 


\section{Key to Microcos in Singapore}

1a. Leaf margin serrate, or dentate to jaggedly toothed towards apex; fruits subglobose to obovoid M. tomentosa

1b. Leaf margin entire; fruits pyriform, obovoid or ellipsoid 2

2a. Fruits pyriform, with pseudostalk M. antidesmifolia var. antidesmifolia

2b. Fruits obovoid or ellipsoid, without pseudostalk 3

3a. Endocarp woody; pyrenes 2-3, 1-2 sterile pyrenes conspicuous M. latifolia

3b. Endocarp coriaceous; pyrene 1, sterile pyrene inconspicuous 4

4a. Leaf apex blunt acuminate; petioles densely covered with tufted hairs; outer involucral bracts rugose on outer surface M. globulifera

4b. Leaf apex sharp acuminate; petioles densely stellate hairy; outer involucral bracts smooth on outer surface M. hirsuta

ACKNOWLEDGEMENTS. We would like to thank Kenneth Er, CEO, of the National Parks Board, Singapore, for support for the Flora of Singapore project and the subsequent native plant documentation and conservation work. W.W. Seah (SING) and H.K. Lua (National Biodiversity Centre, National Parks Board) assisted in the collection of specimens. W.H. Lim (SING) assisted in the identification of the specimens.

\section{References}

Alverson, W.S., Whitlock, B.A., Nyffeler, R., Bayer, C. \& Baum, D.A. (1999). Phylogeny of the core Malvales: Evidence from $n d h \mathrm{~F}$ sequence data. Amer. J. Bot. 86: 1474-1486.

APG (2009). An update of the Angiosperm Phylogeny Group classification for the orders and families of flowering plants: APG III. Bot. J. Linn. Soc. 16: 105-121.

APG (2016). An update of the Angiosperm Phylogeny Group classification for the orders and families of flowering plants: APG IV. Bot. J. Linn. Soc. 181: 1-20.

Bayer, C. \& Kubitzki, K. (2003). Malvaceae. In: Kubitzki, K. \& Bayer, C. (eds) The Families and Genera of Vascular Plants, vol. 5, pp. 225-311. Berlin: Springer Verlag.

Bayer, C., Faye M.F., De Bruijn, A.Y., Savolainen, V., Morton C.M., Kubitzki, K., Alverson, W.S. \& Chase, M.W. (1999). Support for an expanded family concept of Malvaceae within a recircumscribed order Malvales: A combined analysis of plastid $a t p \mathrm{~B}$ and $r b c \mathrm{~L}$ DNA sequences. Bot. J. Linn. Soc. 129: 267-303.

Chung, R.C.K. \& Soepadmo, E. (2011). Taxonomic revision of the genus Microcos (MalvaceaeGrewioideae) in Peninsular Malaysia and Singapore. Blumea 56: 273-299.

Chung, R.C.K, Soepadmo, E. \& Lim, A.L. (2005). A synopsis of the Bornean species of Microcos L. (Tiliaceae). Gard. Bull. Singapore 57: 101-130.

Davison, G.W.H. (2008). Criteria for determining category of threat. In: Davison, G.W.H., Ng, P.K.L. \& Ho, H.C. (eds) The Singapore Red Data Book, 2nd edition, p. 268. Singapore: The Nature Society (Singapore). 
Wong, H.F., Tan, S.Y., Koh, C.Y., Siow, M.H.J., Li, T., Heyzer, A., Ang, H.F., Mirza Rifqi bin Ismail, Srivathsan, A. \& Tan, H.T.W. (2013). Checklist of the Plant Species of Nee Soon Swamp Forest, Singapore: Bryophytes to Angiosperms. Singapore: National Parks Board and Raffles Museum of Biodiversity Research, National University of Singapore. 